\title{
Lost Circulation in Geothermal Wells: Survey and Evaluation of Industry Experience
}

Malcolm A. Goodman

Enertech Engineering and Research Co.

Houston, Texas 77098

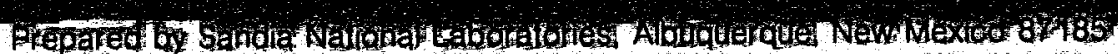

and Livermore, California 94550 for the United States Department of Energy

under Contract DE-AC04-76DP00789

Printed July 1981

Prepared for Sandia National Laboratories under Contract No. 13-8769

\section{[1] Sandia National Laboratories}




\section{DISCLAIMER}

This report was prepared as an account of work sponsored by an agency of the United States Government. Neither the United States Government nor any agency Thereof, nor any of their employees, makes any warranty, express or implied, or assumes any legal liability or responsibility for the accuracy, completeness, or usefulness of any information, apparatus, product, or process disclosed, or represents that its use would not infringe privately owned rights. Reference herein to any specific commercial product, process, or service by trade name, trademark, manufacturer, or otherwise does not necessarily constitute or imply its endorsement, recommendation, or favoring by the United States Government or any agency thereof. The views and opinions of authors expressed herein do not necessarily state or reflect those of the United States Government or any agency thereof. 


\section{DISCLAIMER}

Portions of this document may be illegible in electronic image products. Images are produced from the best available original document. 
Issued by Sandia National Laboratories, operated for the United States Department of Energy by Sandia Corporation.

\section{NOTICE}

This report was prepared as an account of work sponsored by the United States Government. Neither the United States nor the Department of Energy, nor any of their employees, nor any of their contractors, subcontractors, or their employees, makes any warranty, express or implied, or assumes any legal liability or responsibility for the accuracy, completeness or usefulness of any information, apparatus, product or process disclosed, or represents that its use would not infringe privately owned rights.

Printed in the United States of America Available from:

National Technical Information Service

U. S. Department of Commerce

5285 Port Roya1 Road

Springfield, VA 22161

Price: Printed Copy $\$ 4.00$; Microfiche $\$ 3.00$ 
SAND 81-7129

Unlimited Release

Category

Printed July 1981

LOST CIRCULATION IN GEOTHERMAL WELLS

SURVEY AND EVALUATION OF INDUSTRY EXPERIENCE*

Malcolm A. Goodman

Enertech Engineering and Research Co.

Houston, TX 77098

\begin{abstract}
Lost circulation during drilling and completion of geothermal wells can be a severe problem, particularly in naturally fractured and/or vugular formations. Geothermal and petroleum operators, drilling service companies, and independent consultants were interviewed to assess the lost circulation problem in geothermal wells and to determine general practices for preventing lost circulation. This report documents the results and conclusions from the interviews and presents recommendations for needed research. In addition, a survey was also made of the lost circulation literature, of ourrently available lost circulation materials, and of existing lost circulation test equipment.
\end{abstract}

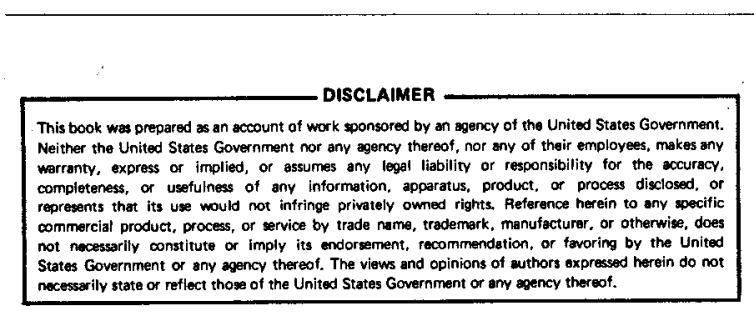

*This report was prepared for Sandia National Laboratories under contract No. 13-8769. 
$, \quad, \quad=$ 
CONTENTS

SUMMARY AND CONCLUSIONS

$\underline{\text { Page }}$

Geothermal Drilling Conclusions

Cementing and Casing Design Conclusions

RECOMMENDATIONS

Full scale Testing Facility

Small Scale Laboratory Equipment

Correlation of Field Experience $\quad 10$

New Cements and Plugging systems 11

Analytical Formation Plugging Modelling $\quad 11$

Logging Tool for Lost Circulation 11

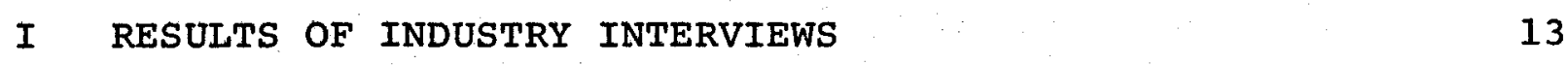

I-1 Interview Procedure and objectives $\quad 13$

$\begin{array}{ll}\text { I-2 Geothermal Regions } & 13\end{array}$

I-2.1 Geysers 13

I-2.2 Imperial Valley 14

I-2.3 Utah 15

$\begin{array}{lll}\mathrm{I}-2.4 \text { Baca } & 15\end{array}$

I-2.5 LASI Hot Dry Rock 15

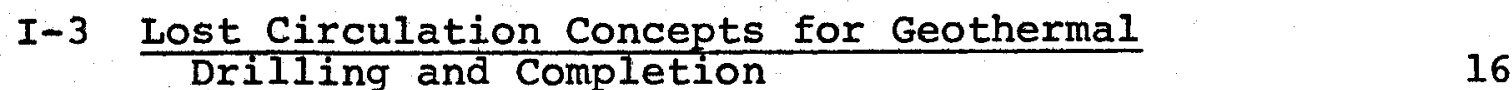

I-3.1 Causes of Lost Circulation 16

I-3.2 Selection of Lost Circulation Materials 17

I-3.3 Cementing Consideration 17

I-3.4 Swelling Shales Together with Lost
Circulation

I-3.5 New Concepts and Alternatives to
Cement Squeezes

I-3.6 Equipment Solutions to Lost
Circulation

I-3.7 Casing Considerations 20

I-3.8 Detection and Evaluation Methods 20 
II SURVEY OF MATERIALS AND TESTING EQUIPMENT

Page

II-1 Literature Search

II-1.1 Search Procedure $\quad 21$

II-1.2 Literature Search Results 22

II-1.2.1 Patents Categorization : : 22

II-1.2.2 Papers Categorization $\ldots, 22$

II-2 Lost Circulation Materials $\quad \cdots \quad 22$

II-3 Testing Equipment $\quad \cdots \quad 23$

II-3.1 API Tester 23

II-3.1.I Equipment Description . 23

II-3.1.2 Test Procedure 24

II-3.2 IMCO Tester $\quad 25$

REFERENCES $\quad 27$

APPENDIX A--Interview Questions and Topics 33

APPENDIX B--Daily Record of Lost Circulation Experience in Phillips Well \#82-33 Roosevelt LeaseUtah

APPENDIX C--Patent References Selected From

Literature Search

APPENDIX D--Technical Papers from Literature Search

TABLES

$\underline{\text { Table }}$

1 Lost Circulation Literature Search, Number of References Selected

By Key Words

2 Lost Circulation References, Breakdown' According to subject Category 30

3 Lost Circulation Materials, Suppliers and Tradenames 
Based on results from our survey of industry experience, geothermal operators are using conventional petroleum methods for fighting lost circulation problems. These range from LCM to gunk squeezes. Our survey indicates that these methods may or may not be successful in overcoming lost circulation, depending on particular downhole conditions. At present, we are not aware of any major new advancements in methods or materials put forth to solve geothermal lost circulation problems.

\section{Geothermal Drilling Conclusions}

The following observations and conclusions summarize current drilling practices for handiing lost circulation in geothermal wells:

1. In sedimentary formations such as the Imperial Valley, lost circulation is not a severe problem. Use of LCM, low mud weight, solids control, and proper hydraulics for hole cleaning are sufficient for handling lost circulation when it occurs.

2. The worst conditions for lost circulation occur in low pressure fractured and/or vugular formations, such as the Geysers. Geothermal and petroleum operators believe that pressure parting and thermal stress cracking due to drilling contribute to the problem, but to what extent is unknown. In these fractured and vugular formations, LCM is generally tried first, followed by cement plugs, followed by blind drilling as a last resort.

3. Shale swelling and wellbore instability can accompany lost circulation. Low mud weight for lost circulation control may not generate sufficient downhole pressure to stabilize shale zones. Reduced flow rates above lost circulation intervals cause hole cleaning problems and increased fill on bottom. These problems can lead to stuck pipe. With low mud weights, proper mud chemistry is important for control of shale swelling. If wellbore instability is severe and cannot be controlled, the general practice is to set casing to provide wellbore support before commencing with deeper drilling.

4. Concentric drill pipe has been tried by some operators, but the concerns of persons interviewed is that the extra cost in equipment and rig time does not justify its use. Although concentric drill string may prevent lost circulation of mud during drilling, the problem during cementing of casing remains.

\section{Cementing and Casing Design Conclusions}

When LCM is not effective, setting of cement plugs is the common practice for sealing lost circulation zones. Numerous 
plugs are often required in order to completely seal a lost circulation interval. From our survey of industry experience, the following conclusions are offered:

1. Cement plugging of lost circulation zones in geothermal wells is often unsuccessful, particularly on the first attempt. The major reason is downhole temperature which is not known accurately enough for determining needed amounts of retarder. Also, movement of formation water and wellbore fluids can wash away the cement slurry or inhibit the setting reaction.

2. Diesel oil-bentonite-cement gunk squeezes, which are used successfully by the petroleum industry to combat severe lost circulation, are generally not used in geothermal drilling because of environmental reasons associated with the diesel oil component. Furthermore, gunk squeezes are difficult to properly design for geothermal wells since the annulus fluid level above the lost circulation zone is not usually known.

3. Sodium silicate systems are being used by some geothermal operators to control total loss of circulation. The sodium silicate gel is pumped into the lost circulation zone ahead of cement, and forms a barrier to retain the slurry while it sets.

4. When setting casing through a lost circulation interval, a liner and tieback string are recommended. The liner can be cemented from above and below to ensure a good cement job. Once the liner is set opposite the lost circulation zone, the tieback string can be cemented through a full-opening port without loss of circulation. The full cemented tieback string has no casing wear from drilling and is undamaged from tripping, fishing, plugging, and other operations.

5. Casing problems can result from poorly cemented lost circulation sections. Eccentric loads and stress concentrations can occur due to unequal cement support around the casing. Exposure to formation fluids, particularly flowing fluids, can cause corrosion, pitting, and wear along with hot spots and thermal strains in the casing.

\section{RECOMMENDATIONS}

The conclusions presented in the previous section indicate that little $R \& D$ effort is presently directed at lost circulation problems in geothermal wells. The state-of-the-art relies on conventional technology. We believe that $R \& D$ can make a significant contribution. 
Six specific research areas have been identified from the industry interviews. These are discussed separately below.

Full scale Testing Facility

In order to evaluate lost circulation materials and procedures under field parameters and to understand the effects of dowhole conditions, it would be advantageous and economical to perform full scale tests in a laboratory before going to the field. This requires a facility for performing tests under simulated field situations. Such a facility does not presently exist, and, hence, any new developments for control of lost circulation can only be tested in the field. Not only arefield site preparation and rig time expensive, but field testing provides only limited information because downhole conditions cannot be varied and downhole measurements are difficult to obtain.

It is recommended that a full scale testing facility be designed and constructed. The apparatus should have capability to independently simulate the following downhole conditions:

1. Full diameter borehole

2. Wellbore circulation flow at variable flow rates

3. Circulating fluids of different types, including cements and polymers

4. LCM at various concentrations

5. Formation rock types

6. Rock permeability, including fractures and vugs

7. Insitu rock stresses and pore pressures

8. Wellbore pressures and equivalent circulating densities

9. Fluid temperatures and formation temperatures.

Small Scale Laboratory Equipment

In adition to full-scale testing under simulated field conditions as discussed in the above section, it would be practical to test the plugging capability of LCM in a "dual flow mode" rather than a single flow mode as is done in existing equipment (see section II-3 on the API and IMCO testers). The API and IMCO equipment use a slot aligned with the flow direction so that flow stops when the slot is bridged and plugged. This means the slot experiences the full dynamic pressure of the flow, rather than the 
actual normal pressure as in a wellbore. Under such conditions, plugging characteristics and plug strength as measured in the test may not be representative of field behavior.

To better simulate field flowing conditions, a dual flow tester is recommended where flow through the slot (simulating a fracture or permeabilityl is independent of flow pass the slot (simulating a wellbore). This requires a flow channel with slots perpendicular to the channel, providing one flow inlet and two flow outlets. Such a device should have capability to provide back pressure on the slot independent of the channel outlet pressure. Formation pressure and wellbore pressure can then be simulated simultaneously. High temperature capability should also be included.

Correlation of Field Experience

The first step in a $R$ \& $D$ program on lost circulation should be compilation and correlation of existing industry experience. A detailed survey and evaluation of well data and drilling reports should be undertaken to determine specific downhole conditions leading to lost circulation problems. The success rate of different remedies for different downhole conditions should be identified. Problems unique to either petroleum or geothermal operations, as well as problems common to both, should be considered in order to evaluate all factors that may affect lost circulation. It is recommended that the following four lost circulation categories be considered separately since each represents a distinct problem:

1. Drilling large holes

2. Rapid drilling

3. Drilling through abnormal pressure zones

4. Drilling through naturally fractured and/or vugular zones .

The first two categories constitute drilling-induced problems related to hole cleaning capability and equivalent circulating densities. The last two categories are formation-induced problems.

Although the four categories represent separate causes of lost circulation, the categories can be interrelated and this is important for evaluating the primary causes of specific problems. For example, categories 1 and 2 can aggravate and magnify categories 3 an 4 and, conversely, categories 3 and 4 can lead to drilling induced problems similar to categories 1 and 2 . The latter situation occurred in the Los Alamos wells described in Section I-1.3.

Information and experience within each category should prove useful for evaluating the influence from other categories. Results from a study of this type will not only provide a data base for lost circulation, but will also serve to identify technical areas for future research. In addition, the results can be used for interpreting new concepts and for testing and evaluation of analytical models. 


\section{New Cements and Plugging Systems}

Research on materials for plugging of geothermal formations should be updated. The study should consider, not only plugging capability, but also handling, pumping, and placement techniques. The investigation should emphasize methods and materials for plugging fractured and vugular formations.

In our literature search on lost circulation (see section II-1), more than two-thirds of the references were patents, all of which deal with methods and materials for formation plugging as shown in Tables 1 and 2 . We recommend that these patents be further evaluated. Many of the patents are associated with sand consolidation systems and placement techniques for sand control purposes. Others are related to selective plugging for reservoir injection and secondary recovery purposes. Materials, equipment, and methods developed for these applications may have use for lost circulation.

\section{Analytical Formation Plugging Model}

An analytical model of lost circulation would be useful for:

1. Evaluation of the various parameters that affect formation plugging and lost circulation, and

2. Design of remedial procedures for specific well conditions.

Many parameters influence lost circulation. Drilling parameters include drilling rate, circulation rate, mud rheology, LCM size and concentration, and wellbore geometry. Formation parameters include pore pressure, overburdén stresses, permeability, fracture or vug size, and geothermal temperatures. A mathematical model that incorporates these parameters as variables should be formulated in terms of fluid mechanics principles.

The model should be tested and correlated with field data and sensitivity studies should be performed on the dependent parameters. The sensitivity studies will identify the most important variables.

With an analytical model, design considerations can be evaluated for control of lost circulation under given field conditions. It may be possible to construct charts or nomographs for selection of drilling parameters and lost circulation materials for specific well conditions.

\section{Logging Tool for Lost Circulation}

size of formation fractures and vugs should be known in order to properly bridge and plug lost circulation zones. A wellbore tool for measurement of fracture/vug size would be useful for design of remedial procedures. It is recommended that development of a logging type tool for this purpose be undertaken. 
$\therefore$ 
I-1 Interview Procedure and Objectives

To assess current drilling and completion practices for handling lost circulation in goethermal wells, industry representatives were interviewed by direct contact and visits. The interview format was based on the discussion topics and questions as outlined in Appendix A. Four geothermal operators, two petroleum operators, three drilling service companies, and two consulting companies comprise the interview group. The specific objectives of the interviews were the following:

1. Identify the common causes for lost circulation in geothermal wells.

2. Evaluate the general procedures for preventing lost circulation from occurring and the methods used for overcoming lost circulation after it has occurred.

3. Compare findings from the geothermal and petroleum industry and draw on petroleum experience to determine potential solutions for application to the geothermal industry.

4. Make recommendations for new approaches and for needed research to solve the lost circulation problem in geothermal wells.

Objectives 1, 2, and 3 were achieved directly from the interviews. Each region is discussed separately below. The results of the interviews and an overall assessment of geothermal lost circulation are presented above in the Summary and Conclusions section. Objective 4 on recommendations is also discussed above in the Recommendations section.

I-2 Geothermal Regions

1-2.1 Geysers In the steam dominated Geyser field, reservoir pressure is low, compared to the higher pressures of the water dominated reservoirs in Utah and Baca. This can magnify the lost circulation problem because of drilling induced pressure parting of the rock formations. Operators are uncertain whether lost circulation in the Geysers is governed principally by pressure parting or by natural fractures and vugs, and to what extent the two mechanisms interact and contribute to the problem. 
The present solution for lost circulation control involves cement and sodium silicate. If the loss is partial, then lost circulation additives (usually mica or walnut hulls) and/or straight cement are used. Total loss is controlled with cement preceded by sodium silicate gel. Gunk squeezes are not used because of environmental factors and because of the difficulty in determining mixture ratios for the squeeze. Without annulus fluid levels, the balanced plug method for designing a gunk squeeze cannot be used to calculate proper mixture ratios.

Open hole logs are not generally run in the Geysers. Borehole detection devices such as spinner surveys and borehole televiewers are not generally used. The existing version of borehole televiewer cannot withstand the elevated temperatures, but the U.S. Geological Survey has developed a new model which may be serviceable. Presently, operators cannot specifically identify and accurately locate individual lost circulation zones in open hole. In cased holes, the cement bond $\log$ is run, but is not dependable for locating lost cement zones or voids behind pipe.

Concentric drill string has been tried by some operators, but did not perform well and the additional running time caused the system to be uneconomic. major $\frac{I-2.2}{\text { problem in the sedimentary formations of this geothermal region, }}$ LCM is sometimes used due to pressure induced lost circulation. "In general, conventional muds with thinners for high temperature problems and mud densities of $9-10 \mathrm{ppg}$, and good drilling practices with effective rheology, hydraulics, and solids control to maintain the proper equivalent circulating density, will prevent lost circulation problems from occurring in the Imperial valley.

In theory, lost circulation material should not be needed in the Imperial valley, but in practice ICM is helpful, particularly in the very permeable sediments. Lost circulation creates a reduction in annulus pressure which complicates the ability to control lost circulation through mud weight alone. Grain size selection methods for lost circulation material do not always correlate in the Imperial valley with formation plugging needs. LCM seldom stops lost circulation, but usually reduces it significantly.

With regard to cementing in the Imperial Valley, operators are not aware of lost circulation problems, even though cement weights exceed $9 \mathrm{ppg}$. Remedial cementing is sometimes necessary because of cement fingering caused by underground water percolation.

Two types of casing problems in the Imperial Valley are noted. one is corrosion associated with underground water percolation which could be due to improper cement sealing resulting from lost circulation during cementing. The other is thermal parting and/or buckling due to temperature changes during operations. 
I-2.3 Utah Most experience with lost circulation has occurred in the Roosevelt lease. Depth to the top of the reservoir at Roosevelt varies across the field between 1200-7500 feet. Lost circulation occurs in the granite which is covered by a mantle of sedimentary formations.

No casing problems such as buckling or thread jump have occurred at Roosevelt, even though 10-20 cycles of on-off production have taken place.

Concentric drill string was considered and was inquired into for driling lost circulation zones but has not been used. The borehole televiewer has been used in some wells after drilling to inspect fractures, but generally such detection methods and sens' ing devices for lost circulation evaluation are not used.

In one Roosevelt well, lost circulation was particularly severe. The problem was aggravated in part by the fact that no formation fluids were encountered during driliing of the lost circulation zone and, hence, fluid pressure differential was highly overbalanced. The well is presently used for reinjection of fluids produced during tests in nearby production wells. When first used as an injector, the well would not accept all fluid injected and the casing was then perforated opposite the lost circulation zone. No injection problems have occurred since. Initially, after perforating, the well lost injection fluid to the lost circulation zone with no fluid standing in the casing. But after a number of injection periods, the well began holding fluid, indicating that the lost circulation zone became less permeable.

The lost circulation problem in the Roosevelt well started at 1655 feet when the drill pipe dropped two feet. Approximately two weeks were required to drill ghrough the lost circulation zone from 1655-2000 feet. The extra cost in rig time and materials represented a major part of the total well cost. The day-by-day experience through the lost circulation zones in this well is documented in Appendix $B$ and demonstrates the severity of the problem llost circulation materials used include large amounts of lumped coal, alfalfa cubes, and plastic bags filled with wood and barite).

I-2.4 Baca In the Baca area, lost circulation is a problem in fractured rock of the Bandalera tuff, causing water flows from above in the Caldera fill because of pressure unbalance. The water influx into the wellbore is accompanied by hole caving and sloughing, generating additional drilling problems. If lost circulation results in partial loss of returns, then use of lost circulation material in the drilling mud is normally tried. If the loss is total, then cement spotting and squeezing is used.

I-2.5 LASL Hot Dry Rock Severe lost circulation problems have occurred during drilling of the wells for the Los Alamos Hot Dry Rock project. In these wells lost circulation in vugular limestone is complicated by swelling shales above the limestone and unexplained casing failures. Present approach for handling the lost circulation is to set casing immediately above and below the thief zone. In one well, concentric drill string was successfully used over a portion of the hole for control of lost circulation. 
of particular interest are the casing failures (holes and splits in the casing wall) experienced in the EE-2 well after drilling and cementing were completed. Such failures may be related to the lost circulation zones which could lead to poor cementing and improper casing support. Thermal stresses may be induced in the casing where formation fluids contact the pipe in partially cemented zones, and overburden loads may cause buckling of casing in unsupported regions. Also, trapped fluids due to poor mud displacement by cement can result in collapse pressures due to thermal expansion. Another source of potential casing problems in poorly cemented sections is corrosion and pitting due to formation fluid movement along the pipe. If the fluid contains formation fines, then erosion and pipe cutting can also occur. Such a situation may result due to fluid circulation down the wellbore from a water zone to a lost circulation zone. The specific reason or causes for the casing problems in the EE- 2 well have not been identified.

A complete description of the lost circulation history in the GT-2 and EE-1 wells is provided in References 1 and 2 .

I-3 Lost Circulation Concepts for Geothermal Drilling and Completion

I-3.1 Causes of Lost Circulation

When lost circulation occurs, it is important that causes be identified in order that proper remedial procedures can be implemented. Lost circulation in petroleum and/or geothermal wells can be grouped into one of the following four categories:

1. Surface Drilling - For surface hole drilling, formations are generally weak and hole diameter is large. Drill solids from the large hole can build up, generating relatively high downhole pressures that may break the formation.

2. Rapid Drilling - High equivalent circulating density can cause pressures that may exceed the closure stress. Fast penetration rates can load the annulus with drill solids, creating rheology and hydraulic problems.

3. Abnormal Pressure - In drilling through high pressure zones, mud weight is normally increased for well control purposes, but lost circulation may result if a low or normally pressured zone is also encountered. General practice is to set casing through the high pressure interval and change back to normal mud weight for deeper drilling. This requires careful casing point selection. Otherwise, both the high pressure interval and the lost circulation zone will be exposed simultaneously in open hole.

4. Fractured Formations - When encountered, the general practice is to add LCM to maintain returns or use a cement squeeze if LMC is unsuccessful. If necessary, the hole should be forced to desired depth, but the lost circulation problem must be solved at each interval before drilling deeper since, otherwise, problems 
can compound or occur later. Casing should be set as soon as possible and the casing shoe should always be tested. Deeper drilling should not commence unless the casing seat holds pressure.

\section{I-3.2 Selection of Lost Circulation Materials}

Without knowledge of porosity or fracture geometry, smaller lost circulation materials should be tried first, with progressively larger LCM used if the smaller materials are not successful. However, as is customary, larger materials are generally tried first with the hope of solving the problem quickly, but this can lead to even greater problems. Larger LCM requires special care in mud handling, pumping is more difficult, and shut-downs are often needed for solids control. Approaching the problem with smaller materials first allows better definition of the downhole problem and provides useful technical information for subsequent operations.

For bridging purposes, the concentration of ICM in the mud is important. For example, with walnut hulls, one operator determined that $10 \mathrm{lb} / \mathrm{bbl}$ is the maximum concentration needed for effective plugging. Greater concentrations do not increase the bridging capability and do cause solids control problems. If $10 \mathrm{lb} / \mathrm{bbl}$ concentration does not plug the lost circulation zone, then a $50 \mathrm{lb} / \mathrm{bbl}$ pill should be spotted into the interval.

As a general rule, ICM bridging of fractures requires that the maximum particle size diameter be one-half the fracture width and that 58 by volume of mud solids be bridging size. ICM size gradation is then required for complete control of lost circulation. This is usually built into most LCM because of the grinding process used for manufacture, which provide the full range of coarse, medium, and fine particles.

In addition to bridging and plugging characteristics, the ICM compressive strength at downhole temperatures is a critical parameter for geothermal drilling. After placement, an LCM plug must be designed to withstand wellbore differential pressure across the plug.

\section{I-3.3 Cementing Considerations}

A major problem with cement squeezing and plugging of lost circulation zones is determining the temperature at which the 
slurry reaches bottom so that squeezes can be properly designed with retarder or accelerator. If actual temperature is greater than expected, then the slurry may set in the drill string causing an expensive clean-out. If, on the otherhand, the temperature is less than expected, the set time will be excessive and will probably result in the slurrv flowing out the lost circulation zone before it sets. Ideally, the slurry should begin to set as it is pumped into the lost circulation zone, but this is very dependent on downhole temperature.

Cement may not be the optimum fill material if lost circulation is pressure induced. Cementing pressures will not only overexpand previously induced fractures, but may also create new fractures. Iight weight fill material that can expand during setting would reduce pressure parting and provide an effective seal after placement. Such a fill material for high temperature application has not been developed.

In geothermal wells, cement squeezes may not set properly because of water movement around the slurry after placement. Light weight cements which generally require longer setting times are particularly susceptible to washing away.

Cement plugs in lost circulation zones may hinder cementing of casing. Wellbore obstructions caused by cement plugs can generate problems when running casing, displacing mud, and circulating cement.

\section{I-3.4 Swelling Shales Together with Lost Circulation}

With both lost circulation and swelling shales as in the Los Alamos wells, mud weight has both positive and negative effects. Low mud weight is needed for lost circulation control, but the reduced hydrostatic mud pressure causes shales to swell. This can only be countered with proper mud chemistry that inhibits shale swelling. In shale zones above lost circulation intervals, the lower flow rates imply less carrying capacity and greater hole fill, and together with shale swelling, generate greater tendency for stuck pipe. This explains the stuck pipe problems encountered in the Los Alamos wells:

\section{I-3.5 New Concepts and Alternatives to Cement Squeezes}

Bentonite-diesel-cement gunk squeezes are regarded by operators as having high potential for control of total lost circulation, but these systems must be properly designed and implemented to be successful and, furthermore, the diesel component may not be acceptable for environment reasons. With some research, it may be possible to replace the diesel with another constituent that is environmentally acceptable. 
An active research program was undertaken by one drilling service company to solve lost circulation in the Geysers [3]. The research involves sodium silicate as a sealing agent. The project was undertaken with the objective. of formulating an additive to drilling mud to create a cement-type system, without the need to use cementing equipment and cement placement procedures. Major advantages of such a system are:

1. Material can be stored on location.

2. Material can be added to mud and left in a pit at the surface. When lost returns occurs, accelerator can be added to the mud and the slurry pumped down the hole.

3. The method eliminates rig time waiting for cementing equipment and personnel.

Temperature problems with conventional cement still exist with the new system which is a combination of cement, clay, silicates and other ingredients. The system is basically retarded and must be accelerated for application depending on bottom hole temperature.

The product is designed for temperatures of $250^{\circ}$ $350^{\circ} \mathrm{F}$, which corresponds to the expected range of operating temperatures in the wellbore. This is cooler than undisturbed geothermal temperatures because of wellbore cooling during drilling and circulation. If the well is static before plugging operations commence, then temperatures will increase.

Thermal set sand consolidation materials are considered to be a viable alternative to cement plugging. Sand coated systems also have potential. Frac gells and special sand carrier fluids used in sand control are not considered good candidates for geothermal applications because of temperature instability. Research and development of high temperature gells should be undertaken.

\section{I-3.6 Equipment Solutions to Lost Circulation}

General consensus among petroleum and geothermal operators is that equipment solutions such as concentric arill string and inflatable packers are not viable for controlling lost circulation. Such methods are not economical, represent overkill, and should be tried only as a last resort. The expense of additional rig time in handling the equipment and for crew training is not justified, particularly in view of the risk that the equipment may not solve the problem. Even if the hole can be drilled with concentric drill string, the cementing problem still remains. Inflatable packers (with or without cement as a filler) raises questions about elastomer instability at 
elevated temperatures. And what if the packer is not properly placed or does not set or seal? Equipment solutions may have application in big holes where lost circulation is magnified, and mud rheology is more difficult to control. As a general practice, operators believe that lost circulation problems, if properly evaluated, can be solved with materials, either LCM and/or cements with additives.

\section{I-3.7 Casing Considerations}

When casing is exposed to geothermal formations because of poor cementing induced by lost circulation, thermal stresses may be generated due to cold spots associated with water movement and corrosion may occur due to solution and temperature electrolysis. A bad cement job can lead to eccentric support and high stress points. If water-based fluids are trapped outside casing, burst or collapse can result from pressure buildup when wellbore temperature exceeds the boiling point, as may occur during production.

For improved cementing of casing opposite lost circulation zones, a liner and tieback string can be used with the following benefits:

1. Lost circulation zones can be squeezed with cement from the top of the liner.

2. Good cement job between tieback string and casing is ensured because the interval opposite the liner has previously been cemented, indicating that the lost circulation zone below will not effect the cement placement in the casing-casing annulus. This eliminates voids and/or pockets of water between casing strings.

3. The tieback system provides a new wellhead valve and production casing string that is undamaged from drilling.

\section{I-3.8 Detection and Evaluation Methods}

Operators are not certain whether lost circulation in geothermal wells is truly unconventional and whether we really know the fracture geometry in these geothermal locations. Also, what are the temperature effects and to what extent does high temperature magnify the conventional lost circulation problem? Lost circulation in a given location can be solved only when the cause is understood and the governing parameters are identified. This suggests the need for detection and evaluation tools. Although lost circulation zones can be identified with methods such as the spinner survey, fracture orientation and width and porosity size cannot be determined with existing tools. 


\section{SURVEY OF MATERIALS AND TESTING EQUIPMENT}

\section{II-1 Literature Search}

As part of the overall assessment of lost circulation in geothermal wells, a literature search on lost circulation in both geothermal and petroleum wells was performed through the Petroleum Abstracts service. The references uncovered in the search were evaluated and categorized according to the following specific subject areas:

1. Concepts and drilling related causes of lost circulation

2. Materials for control of lost circulation

3. Methods of placement and procedures used for formation plugging

4. Detection of lost circulation zones

5. Field cases and examples of past experience.

Each subject area has been summarized and documented and, in this form, serves as a single reference source for quick review.

\section{II-1.1 Search Procedure}

In November 1979, Sandia performed a literature search on lost circulation using two key words - lost circulation and thief formation. Upon review of the Sandia search, it was found that most of the references were keyed from listings in Petroleum Abstracts. It was also determined that three other key words yielded a significant number of additional references. These three key words are:

$$
\begin{aligned}
& \text { Lost circulation additive } \\
& \text { Formation plugging } \\
& \text { Plugging agent. }
\end{aligned}
$$

The Sandia search was computer-based and considered the literature from 1969 to mid-1979. We have expanded the Sandia search in two ways:

1. By searching the additional three key words from 1975 to mid-1979 using the Petroleum Abstracts computer listing, and

2. By manually searching the five key words in the monthly lists published by Petroleum Abstracts from mid-1979 to mid-1980. 
The literature search was initiated by obtaining the complete listing of references under each key world for each year. The listings were reviewed and references of interest were selected. Abstracts of these references were obtained. Based on review of the abstracts, papers were selected as the final step in the search process.

\section{II-1.2 Literature Search Results}

From the many references listed under the key words, a total of 68 references were selected for abstract review. The breakdown according to key word and year is shown in Table 1 . From the 68 abstracts, a total of 59 references were selected, including both patents and technical papers. In Table $I$, the numbers in parentheses represent the division between patents and papers.

Table 2 shows the breakdown of references according to the five subject areas listed above in Section II-1. Appendices $C$ and $D$ list the titles and sources for each of the 59 references, arranged by subject topic for papers and patents with key words identified.

\section{II-1.2.1 Patents Categorization}

Almost two-thirds of the references selected from the abstract review are patents, Table 1 , and of these most were obtained from the two key words, formation plugging and plugging agent. Table 2 shows that the 41 patents all fall within two subject categories, either materials or placement methods.

Most of these patents (see Appendix c) do not apply directly to lost circulation, but are representative of sand consolidation techniques and selective plugging for fluid injection purposes. We believe, however, that these applications may also be appropriate for curing lost circulation, particularly in the fractured and vugular formations of geothermal wells.

\section{II-1.2.2 Papers Categorization}

Only eighteen papers on lost circulation, Table 1, were identified from the search for the years 1975 to mid-1980, suggesting that much of the technical literature on lost circulation was published before 1975. Of interest also is the fact that no papers and no patents applicable to detection of lost circulation zones were found for the period 1975 to mid-1980 (see Table 2).

\section{II-2 Commercial Lost Circulation Materials}

Table 3 is a listing of commercially available lost circulation materials. Most commonly used materials are wood fibers, cane fibers, walnut shells, cottonseed hulls, cellophane flakes, and mica flakes. A combination of fibrous, granular, and flake material is ofter used to give optimum particle size distribution. Many of the materials are available in different grades of fine to course particles. In general, most materials are effective with water-base muds. Wood 
fibers, cane fibers, cellophane flakes, and cottonseed hulls are not recommended for use in oil-base muds.

Plugging. characteristics and strength properties of lost circulation materials are not provided by suppliers. Recommended treatment with LCM is usually based on concentration of LCM in the mud (15-45 ppb) rather than bridging size or strength needed to support differential pressure. Bridging size and strength properties can be determined with the API testing apparatus. It would be advantageous for design of lost circulation treatments to know these properties for the various lost circulation products offered by suppliers. As part of the study recommended for new materials, we suggest that bridging and strength properties of commercial lost circulation materials be compiled.

\section{II-3 Testing Equipment}

From our interviews with operating and service companies, we determined that the API tester is the only equipment presently used by the petroleum industry for evaluating LCM. The IMCO tester was developed in 1979 to investigate an oil base mud at $150^{\circ} \mathrm{F}$, but the apparatus has not been used since by IMCO nor is it available for commercial use. Both the API tester and IMCO apparatus are described in the following sections.

\section{II-3.1 API Tester}

The API recommendations for testing LCM, as reported in API Bulletin RP-13B, are presented below.

\section{II-3.1.1 Equipment Description}

The equipment for use in testing bridging materials for regaining circulation is as follows:

1. Set of $1 / 4 \mathrm{l}(6.4 \mathrm{~mm})$ thick by $1-7 / 8 \mathrm{l}(47.5 \mathrm{~mm})$ diameter stainless steel disks that have square edged slots $1-3 / 8$ " (35 mm) in length and widths of .04 (1.0), $08(2.0), .12(3.0), .16(4.0)$ and $.20(5.0)$ inch $(\mathrm{mm})$

2. Sleeve that is $2-7 / 8 "(73 \mathrm{~mm})$ in diameter, $2-1 / 4 "$ $(57 \mathrm{~mm})$ high having a perforated base plate containing approximately $32-1 / 4 "(6.4 \mathrm{~mm})$ holes

3. Approximately 95 brass or stainless steel marbles 9/16" (14.3 $\mathrm{mm}$ ) in diameter (this should be enough to fill the bed volume)

4. About 1,200 grams of brass-clad or stainless steel BB shot 1.73" $(4.39 \mathrm{~mm})$ in diameter and a 10-mesh stainless steel screen $2-7 / 8^{\prime \prime}(73 \mathrm{~mm})$ in diameter

5. Nitrogen source with pressure regulator

6. $3,500 \mathrm{~cm}^{3}$ graduated plastic container with inlet and outlet suitable to accommodate the sudden discharge of mud from test cell. 


\section{II-3.1.2 Test Procedure}

1a. Prepare a base mud consisting of 5 to 8 percent by weight bentonite. Age for 72 hours and adjust the apparent viscosity to 25 centipoise \pm 2 centipoise.

2a. To a $3,500 \mathrm{~cm}^{3}$ sample of base mud add a weighted amount of test material. The concentration should be expressed in $\mathrm{ppb}$.

\section{Static Slot Test}

1b. Take a disk, preferably with a small slot, and put it in the valve outlet half-union with the perforated plate and sleeve used to support BB or marble beds removed from the cell. Open the cylinder bleed valve to the atmosphere and place the graduated container under the outlet.

$2 \mathrm{~b}$. Pour the mud containing the test material into the cell with the outlet valve open. Make note of the volume of mud which flows out. Place the cap on the cell.

3b. If desired, the free piston can be placed on the fluid in the cell. Start the timer and apply pressure at a rate of $2 \mathrm{psi} / \mathrm{sec}\left(.14 \mathrm{kgf} / \mathrm{cm}^{2}\right)$ until a pressure of $100 \mathrm{psi}(7.03 \mathrm{kgf} /$ $\mathrm{cm}^{2}$ ) is obtained. Make note of amount of mud discharged. If observed, the minimum amount of pressure to make a seal, should be recorded.

$4 \mathrm{~b}$. Add additional pressure at the rate of $10 \mathrm{psi} / \mathrm{sec}$ $\left(.7 \mathrm{kgf} / \mathrm{cm}^{2} / \mathrm{sec}\right)$ to $1,000 \mathrm{psi}\left(70.3 \mathrm{kgf} / \mathrm{cm}^{2}\right)$ or until the seal fails and the cell empties. Record the volume through or the maximum pressure obtained. If a seal is formed, maintain the pressure for 10 minutes and record the final volume.

$5 \mathrm{~b}$. Continue testing using increasing sizes of slots until no permanent seal is achieved at $1,000 \mathrm{psi}\left(70.3 \mathrm{kgf} / \mathrm{cm}^{2}\right)$.

\section{Dynamic Slot Test}

1c. Prepare a base mud as above. (Steps 2a, 1b)

2c. With the outlet valve closed, fill the test cell with mud. If desired, the free piston may be placed on top of the mud. Screw on the cap and set the gas regulator to deliver at a test pressure of $100 \mathrm{psi}\left(7.0 \mathrm{kgf} / \mathrm{cm}^{2}\right)$. Open the outlet valve and start the timer. Make note of the volume of mud which flows through the slot and the time required to form a seal. Pressure can now be raised to $1,000 \mathrm{psi}\left(.7 \mathrm{kgf} / \mathrm{cm}^{2} / \mathrm{sec}\right)$ and maintained for 10 minutes as above. (Step $4 \mathrm{~b}$ )

3c. Repeat the test using increasing sized slots until no permanent seal is achieved. 


\section{Marble Bed and BB Bed Tests}

These are similar to the static and dynamic slot tests except that the cell is filled with marbles or $B B$ shot to simulate porous media. The reader is referred to API Bulletin RP-13B for details.

\section{II-3.2 IMCO Tester}

In October 1979, IMCO designed and constructed a lost circulation test cell to evaluate an oil base mud for a client. With the exception of testing performed for this one application, IMCO has not used the apparatus for any further testing. The IMCO cell is different from the standard API cell for testing lost circulation materials. Cell drawings and test results were requested, but IMCO prefers to keep the information proprietary at this time. No results or description of the apparatus has been published in the technical literature.

The IMCO aluminum test cell consists of a cylinder and slotted insert. The cylinder is 24 inches long with a 4 inch ID and $1 / 2$ inch wall thickness. It is rated for pressure of 500 psi and is equipped with an electric heat strap to impose temperatures up to $150^{\circ} \mathrm{F}$. The cylindrical insert is split lengthwise into two halves that form a wedge-shapped slot along the length of the insert. Slot size is 12 inches vertically and 2.5 inches horizontally with variable slot width depending on the insert halves used in a given test. Different insert halves can be combined to give slot widths of $0.005,0.01,0.02,0.05$, and 0.1 inches. The insert with slot is installed in the cylinder with the larger width of the wedge-shaped slot at the top.

Tests are performed with $1000 \mathrm{cc}$ of mud on top of the slot. Fluid pressure is applied to force the mud through the slot. Duration of each test is one hour with fluid loss readings taken at 15 minute intervals. Results are plotted in terms of fluid loss versus time for each slot size used. Depth in the slot where bridging occurs is observed upon dismantling the insert after each test. 
. 


\section{REFERENCES}

1. Pettitt, R. A., "Planning, Drilling, and Logging of Geothermal Test Hole GT-2, Phase I," Los Alamos Scientific Laboratory Report LA-5819-PR, Issued January 1975.

2. Pettitt, R. A., "Planning, Drilling, Logging, and Testing of Energy Extraction Hole EE-1, Phases I and II," Los Alamos Scientific Laboratory Report IA-6906-MS, Issued August 1977.

3. Green, K., "Lost Circulation: A Major Problem in the Geysers," Proceedings of the Geothermal Research Council Conference in Albuquerque, March 1980. 


$$
\therefore \quad \div
$$


TABLE 1

Lost Circulation Literature Search

Number of References Selected By Key Word

Tabulated Numbers Indicate

Total References (Patents/Papers)

\begin{tabular}{|c|c|c|c|c|c|c|c|}
\hline Key Word & 1975 & 1976 & $\begin{array}{r}\text { YEAR } \\
\quad 1977 \\
\end{array}$ & 1978 & 1979 & $\begin{array}{l}\text { Thru } \\
\text { June } \\
1980 \\
\end{array}$ & Total \\
\hline Formation Plugging & $9(8 / 0)$ & $4(4 / 0)$ & $5(5 / 0)$ & $4(3 / 1)$ & $5(3 / 1)$ & & $27(23 / 2)$ \\
\hline Lost Circulation & $6(1 / 1)$ & $4(0 / 3)$ & $3(0 / 3)$ & & $2(0 / 1)$ & $2(0 / 2$ & $17(1 / 10)$ \\
\hline $\begin{array}{l}\text { Lost Circulation } \\
\text { Additive }\end{array}$ & & & $3(2 / 1)$ & & $2(2 / 0)$ & & $5(4 / 1)$ \\
\hline Plugging Agent & $6(3 / 2)$ & $4(3 / 1)$ & $2(2 / 0)$ & $4(3 / 1)$ & $1(1 / 0)$ & & $17(12 / 4)$ \\
\hline Thief Formation & $1(0 / 1)$ & & & & & $1(1 / 0)$ & $2(1 / 1)$ \\
\hline Total & $22(12 / 4)$ & $12(7 / 4)$ & $13(9 / 4)$ & $8(6 / 2)$ & $10(6 / 2)$ & $3(1 / 2)$ & $68(41 / 18)$ \\
\hline
\end{tabular}


TABLE 2

Lost Circulation References

Breakdown According to Subject Category

Tabulated Numbers Indicate

(Patents/Papers)

\begin{tabular}{|c|c|c|c|c|c|c|c|}
\hline \multirow{2}{*}{$\begin{array}{l}\text { Subject } \\
\text { Category }\end{array}$} & \multirow[b]{2}{*}{1975} & \multicolumn{4}{|c|}{ YEAR } & \multirow{2}{*}{$\begin{array}{l}\text { Thru } \\
\text { June } \\
1980\end{array}$} & \multirow[b]{2}{*}{ Total } \\
\hline & & 1976 & 1977 & 1978 & 1979 & & \\
\hline Concepts & $(0 / 1)$ & $(0 / 2)$ & $(0 / 1)$ & & $(0 / 1)$ & & $(0 / 5)$ \\
\hline Materials & $(9 / 1)$ & $(4 / 2)$ & $(7 / 1)$ & $(2 / 1)$ & $(5 / 0)$ & & $(27 / 5)$ \\
\hline Methods & $(3 / 0)$ & $(3 / 0)$ & $(2 / 0)$ & $(4 / 1)$ & $(1 / 0)$ & $(1 / 0)$ & $(14 / 1)$ \\
\hline Detection & & & & & & & $(0 / 0)$ \\
\hline Field Cases & $(0 / 2)$ & & $(0 / 2)$ & & $(0 / 1)$ & $(0 / 2)$ & $(0 / 7)$ \\
\hline Totals & $(12 / 4)$ & $(7 / 4)$ & $(9 / 4)$ & $(6 / 2)$ & $(6 / 2)$ & $(1 / 2)$ & $(41 / 18)$ \\
\hline
\end{tabular}


TABLE 3

LOST CIRCULATION MATERIALS

Suppliers and Tradenames

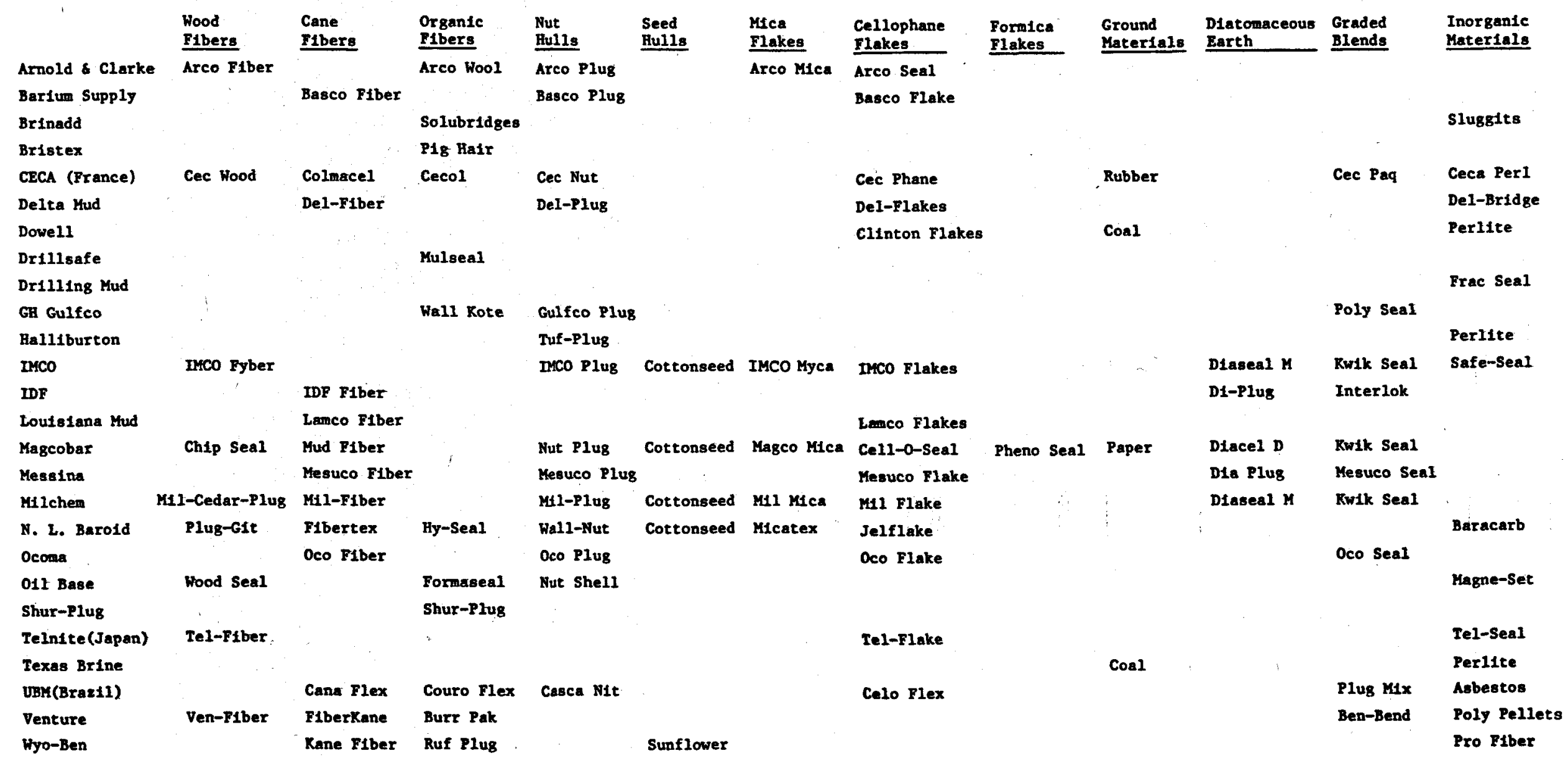




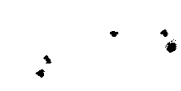




\section{Appendix A: Interview Questions and Topics}

SURVEY OF LOST CIRCULATION EXPERIENCE

IN GEOTHERMAI WELLS

Occurence of Lost Circulation

1. Have you encountered lost circulation problems?

2. How frequently do they occur?

3. Where are fields located?

4. Were hole problems encountered before circulation lost?

5. Did lost circulation occur during drilling, cementing, or both?

\section{Geophysical Information}

1. At what depth is lost circulation biggest problem?

2. In what type formation does it occur?

3. What are insitu pressures?

4. Are open and cased hole logs available?

(Sonic, resistivity, gamma ray, caliper, density, neutron, porosity, temperature, SP, mud gas, cement bond)

\section{Well Data}

1. What are conditions in well at time returns are lost?

2. What type drilling mud present, chemical composition?

3. What is mud weight?

4. What is drilling schedule, and at what arilling rate when circulation lost? 
5. Mud temperature and flow rate?

6. What is casing program?

7. Any cementing problems encountered?

8. Which muds seem to have least problems with lost circulation?

9. Any surface or downhole pressure data?

\section{Well Control Procedures}

1. What precautions are used to prevent lost circulation?

2. When are preventive measures necessary?

3. What procedures are employed to control lost circulation?

4. What materials are used to plug zones, and how successful?

5. Are lost circulation zones isolated with cement plugs?

6. Any problems with well control?

Did gas or water enter well?

7. Any subsequent casing problems near lost circulation zone? (Casing buckling, fluid communication, lack of casing support)

\section{Lost Circulation Studies}

1. Have any special studies of lost circulation been conducted, if so are results available?

2. Have any laboratory experiments been performed for special material or procedures?

3. Have analytical studies of lost circulation causes or prevention been conducted?

4. What recommendations can be made for new or best prevention and control procedures?

5. What studies might be useful to better understand lost circulation? 
Appendix B: Daily Record of Lost Circulation Experience in Phillips Well \#82-33 Roosevelt Lease-Utah

Date

11-19-75 Lost returns at 1655' - 165.7', Fractured formation, Mixed pit with 308 LCM, Drilled to 1678 , No returns

11-20-75 Lost 1400 bbls mud

Pumped 300 bbls mud, $35 \%$ LCM, Hole filled to $50^{\circ}$ Pumped 300 bbls mud, $35 \%$ Lost circulation material

Pumped 100 bbls mud in drill pipe, 25 bbls mud in annulus, No returns

Pumped high water loss pill, No returns

Mixed 1 pit mud, 358 LCM, Pumped in hole

Mixed and pumped 50 sacks Class B cement, Tagged top of cement

11-21-75 Mixed and pumped 50 sacks Class B cement, Tagged cement

Mixed and pumped 50 sacks Class B cement, Tagged top of cement at $1647^{\prime}$

Dropped 2 tons alfalfa cubes plus 300 bbls of water, No fill in hole

Dropped $1-1 / 2$ tons alfalfa cubes plus 200 bbls water, No $f i l 1$

Dropped 200 gallons soaked burlap sacks

Dropped $1-1 / 2$ tons alfalfa cubes plus 200 bbls of mud, 358 LCM

11-2.2-75 Bit in hole, No fill

Pumped 200 gelled burlap sacks

Pumped 3 tons lumped coal (6" - 9" size)

Pumped 2 tons alfalfa cubes

Hole filled up

Drilled bridges to $1650^{\prime}$, Lost returns

11-23-75 Dropped 180 burlap sacks in hole

Dropped 1 ton lumped coal (6" - 9" size)

Dropped 2-1/2 tons alfalfa cubes in hole

Dropped 2 tons lumped coal in hole

11-24-75 Bit drilled bridges to 750 ', Lost returns

Bit to 1650', Hole clear

Dropped 7 plastic bags filled with mud (10" OD $\times 15^{\prime}$ 'long) followed with gelled mud

Hole clear to $1658^{\circ}$

11-25-75 Dropped 2 tons lumped coal in hole

Pumped 1 pit mud, $35 \%$ LCM, Drilled bridges 1675'

Spot 150 sacks barite plug, No fill

spot 150 sacks barite plug, No fill

Pumped 1 pit mud, 358 LCM 
11-26-75 Dropped 400 plastic bags filled with wood chips and barite in hole, flushed with 400 bbls mud, No fill

11-28-75 Flushed 420 gallons diesel oil

Flushed 840 gallons diesel oil mixed with 6 gallons DOC \#12

Flushed with 200 sacks Class B cement

11-30-75 Drilled 12 hours, No returns

Drilled 15 hours to $2004 \%$. Tried to run logs

12-2-75 Ran 9-5/8", 40 ppf casing, Set at 2001:

Pumped 200 sacks Class B cement plus silica flour

Pumped 600 sacks Class B cement plus silica flour

Drilled to $2160^{\prime}$, Lost returns

Pumped mud with coarse mica flakes, Fibertex, Plug-It, Cotton seed hulls

Pumped mud containing High-Seal paper

Drilled to $2240^{\prime}$, Full returns

Carrying 12\% LCM in mud

12-4-75 Full returns 
Appendix C: Patent References Selected From Literature Search

PATENTS (41 References)

SUBJECT CATEGORY: MATERIALS

1975 Key Word: Formation Plugging

1. Asphalt Plug Emplacement Process

2. Method of Alleviating Iost Circulation

3. Plugging or Sealing Fractures in Formations

4. Process for Closing or Filling In Narrow Fractures or Fissures or Cavities in Rock

5. Sealed Porous Earth Formations and Process for their Manufacture

6. Subsurface Formation Treatment

1975 Key Word: Plugging Agent

7. Sealant

8. Use of Radiation - Induced Polymers as Temporary or Permanent Diverting Agent

9. Aluminate - Thickened Well Treating Fluid and Method of Dse

\section{Formation Plugging}

10. Method for Treating Subterranean Formations with Cellulose Ether Polyacrlamide Aqueous Gels

11. Plugging Subterranean Regions with Acrylic-Epoxy Resins with Resin Forming Emulsions

12. Water-Insensitive System, In Particular for Sealing and Consolidating Water-Bearing Geological Formations
Petroleum Abstracts Number

214,808

208,409

200,442

207,114

202,088

199,068

204,388

208,545

204,392

226,133

219.769

227,402 
1976 Plugging Agent

13. Method for Reducing Formation Permeability 217,873 with Gelled Polymer Solution Having Delayed Gel Time

\section{Formation Plugging}

14. Controlled Well Plugging with Dilute Polymex

15. Method for Sealing a Permeable Subterranean Formation

16. Timing the Deposition of an Asphalt Plugging Material from an AsphaltCationic Emulsion

17. The Consolidation of Particles with Aqueous Emulsions of Epoxy-Resin Components.

1977 Key Word: Lost Circulation Additive

18. Restoring Lost Circulation

\section{Plugging Agent}

19. Gel Formation by Polymer Crosslinking 240,706

20. Method for Preventing Fluid Migration in 235,535 Coal Seams

\section{Formation Plugging}

21. Plugging Permeable Earth Formations 247,919 with Wax

1978 Plugging Agent

22. Soil Consolidation Method

1979 Formation Plugging

23. Lignosulfonates for High-Temperature Plugging 
24. Sealing Wells

267,670

25. Sealing High Permeability Earth Strata

258,772

1979 Lost Circulation Additive

26. Drilling of Subterfanean Formations with Drilling Fluids Containing Fluid Loss Agents

257,909

1979 Plugging Agent

27. Composition of Matter Useful for Earthen Formation Treatment

258,151

SUBJECT CATEGORY: METHODS

1975 Formation Pugging

1. Method for Producing Petroleum

203,407

2. Shallow Plugging Selective Re-Entry 200,111 Well Treatment

1975 Lost Circulation

3. Process for Cementing Wells

1976 Formation Plugging

4. Partially Crosslinked Polymer used in 228,402 Correcting Subterranean Formation Permeability

1976 Plugging Agent

5. Compositions Useful in Plugging Formations 217,594

6. Selective Plugging of Formations 218,873 with Foam

1977 Formation Plugging

7. Plugging a Subterranean Reservoir with a 232,200 Self-Sealing Filter Cake 
1977 Lost Circulation Additive

8. Lost Circulation Control

230,028

1978 Formation Plugging

9. Method of Treating Wells

256,623

10. Plugging Earth Strata

253,302

1978 Plugging Agent

11. Method Using Lignosulfonates for High

Temperature Plugging

251,790

12. Plugging of Water-Producing zones in a Subterranean Formation

256,380

\section{Lost Circulation Additive}

13. Method and Apparatus for Continuously Separating Lost Circulation Material from Drilling Fluid

1980 Thief Formation

14. Process for Reducing Fluid Flow To and From a Zone Adjacent to a Hydrocarbon 277,577 Producing Formation 
Appendix D: Technical Papers from Literature Search

PAPERS (18 References)

SUBJECT CATEGORY: CONCEPTS (5 References)

1975 Key Word: Lost Circulation

1. Handling Lost Circulation Requires Judgement 198,790

1976 Lost Circulation

2. Lost Circulation Complicates Well killing 217,379 Operations

3. Stop Lost Circulation by Controlling ECD 217,567

1977 Lost Circulation

4. Transient Pressure Surges due to Pipe 242,525 Movement in an Oil Well

1979 Formation Plugging

5. Good Procedures Ensure Open Hole 265,890

Plug Success

\section{SUBJECT CATEGORY: MATERIALS (5 References)}

1975 Plugging Agent

1. A New Approach to Permeability Ređuction 207,757

1976 Lost Circulation

2. How to Use a Systems Approach to 222,510

Combat Lost Circulation 
1976 Plugging Agent

3. A Gel Diverting Agent Used in Acidizing 221,875 Treatments

1977 Lost Circulation Additive

4. New Lost Circulation Remedy is Easy to Use 233,797

1978 Plugging Agent

5. An Acrylic/Epoxy Emulsion Gel System

for Formation Plugging: Laboratory

Development and Field Testing for Steam

Thief zone Plugging

SUBJECT CATEGORY: METHODS (1 Reference)

1978 Formation Plugging

1. New Methods Make Downhole Liquid Plugging 249,436

Practical

SUBJECT CATEGORY: FIELD CASES (7 References)

1975 Plugging Agent

1. Field Results of a short setting

211,970

Time Polymer Placement Technique

1975 Thief Formation

2. A Case Study of Thief zones in a 205,541 California Waterflood

\section{Lost Circulation}

3. An Improved Lost Circulation $\quad 239,456$

Squeeze Slurry

4. Water Flows, Lost Circulation Common

in Middle East Drilling 
1979 Lost Circulation

5. Sensitive Delta-Flow Method Detects

267,086 Kicks or Lost Returns

\section{Lost Circulation}

6. Use of Low Solids - Low Weight Mud Improves Drilling Performance

272,471

7. Experience and Results of Removing 275,941 Circulation Losses in Mesozoic Sediments 
DISTRIBUTION :

TID-4500-R66-UC-66C (675)

Amoco Production Company

Research Center

P. O. Box 591

Tulsa, Oklahoma 74102

Attn: K. Millheim

Dresser Industries, Inc.

P. O. Box 24647

Dallas, Texas 75224

Attn: J.W. Langford

Dyna-Drill

P. O. Box C-10576

Irvine, California 92713

Attn: L. Diamond

Halliburton

Drawer 1413

Duncan, Oklahoma 73533

Attn: D. Smith

Loffland Brothers Company

P. O. Box 2847

Tulsa, Oklahoma 74101

Attn: H. E. Mallory

Los Alamos National Laboratory

Mail Stop 570

Los Alamos, New Mexico 87545

Attn: J. C. Rowley

Mobil Research and Development Corporation

Field Research Laboratory

P. O. Box 900

Dallas, Texas 75221

Attn: W. Gravley

NL Baroid Petroleum Services

City Centre Building, suite $365 \mathrm{~W}$

6400 Uptown Boulevard

Albuquerque, New Mexico 87110

Attn: G. Polk

NL Petroleum Services

P. O. Box 1473

Houston, Texas 77001

Attn: J. Fontenot 
DISTRIBUTION (Continued)

otis

P. O. Box 34380

Dallas, Texas 75243

Attn: W. D. Rumbaugh

Phillips Petroleum Company

P. O. Box 239

Salt Lake City, Utah 84110

Attn: E. Hoff

Smith Tool Company

P. O. Box C-19511

Irvine, California 92713

Attn: J. Vincent

Texas A\&M University

College Station, Texas 77843

Attn: Professor M. Friedman

Dept. of Geology

Shell Oil Company

Two Shell Plaza

P. O. Box 2099

Houston, Texas 77001

Attn: W. E. Bingman

Union Geothermal Division

Union Oil Company of California

Union Oil Center

Los Angeles, California 90017

Attn: D. E. Pyle

U. S. Department of Energy

Division of Geothermal Energy

Mail Station 3344

12th \& Penn, N.W.

Federal Building

Washington, D.C. 20461

Attn: C. McFarland

C. Carwile

M. Skalka

R. LaSala

R. Holliday, Jr. 


\section{DISTRIBUTION (Continued)}

U.S. Department of Energy (2)

Geopressure Projects Office

Suite 8620, Federal Bldg.

515 Rusk Street

Houston, Texas 77002

Attn: F. L. Goldsberry

$\mathrm{R}$. Westhusing

400 C. Winter

1000 G. A. Fowler

2000 E. D. Reed

2300 J. C. King

2500 J. C. Crawford

4000 A. Narath

4200 G. Yonas

4300 R. L. Peurifoy, Jr.

4400 A. W. Snyder

4500 E. H. Beckner

4700 J. H. Scott

4710 G. E. Brandvold

4730 D. G. Schueler

4740 R. K. Traeger

4741 J. R. Kelsey (15)

4743 H. C. Hardee

4746 B. Granoff

4747 P. J. Hommert

4748 B. E. Bader

4750 V. L. Dugan

4751 J. R. Tillerson

4754 A. F. Veneruso

4756

5000

5600

J. K. Galt

3141 T. L. Werner (5)

3151 W. L. Garner (3)

8266 E. A. Aas 